\title{
The Aguada Limestone of Northwestern
}

\section{Puerto Rico}

By WATSON H. MONROE

CONTRIBUTIONS TO STRATIGRAPHY

G E O L O I C A L S U R V E Y B U L L E T I N 1274-G

Prepared in cooperation with the Commonwealth of Puerto Rico

Economic Development Administration, Industrial Research Department

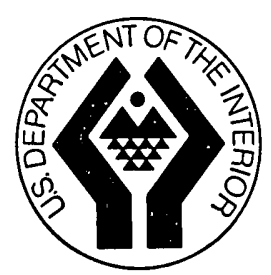




\title{
UNITED STATES DEPARTMENT OF THE INTERIOR
}

STEWART L. UDALL, Secretary

\author{
GEOLOGICAL SURVEY
}

William T. Pecora, Director Washington, D.C. 20402 - Price 10 cents (paper cover) 


\section{CONTENTS}

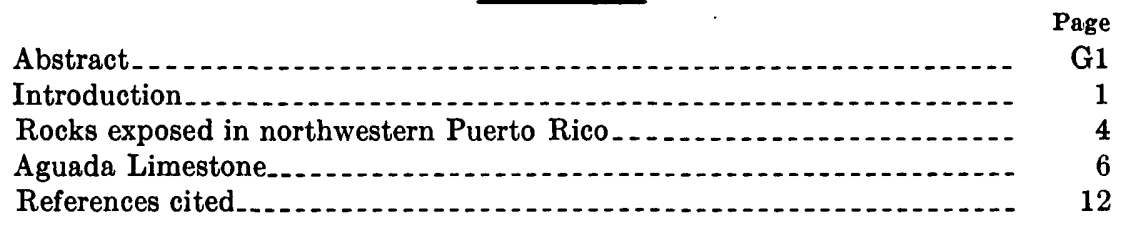

\section{ILLUSTRATIONS}

Figure 1. Map of northwestern Puerto Rico showing geologic contacts as mapped by Zapp, Bergquist, and Thomas...............

2. Map of northwestern Puerto Rico showing geologic contacts

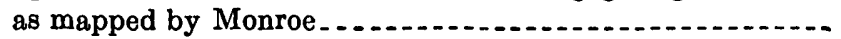

3. Diagrammatic section showing rocks exposed in northwestern

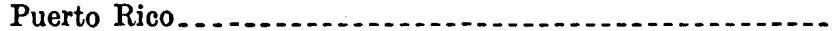




\title{
CONTRIBUTIONS TO STRATIGRAPHY
}

\section{THE AGUADA LIMESTONE OF NORTHWESTERN PUERTO RICO}

\author{
By Watson H. Monroe
}

\begin{abstract}
Geologic mapping in 1966 and 1967 has shown that the strata exposed in the area near Aguada, chosen as the type area of the Aguada Limestone, are a westward extension of strata probably belonging to the Cibao Formation that underlies the Aguada Limestone. The closest outcrops of limestone equivalent to the Aguada Limestone as mapped elsewhere in Puerto Rico are approximately 5 kilometers northeast of Aguada. As the name Aguada is firmly entrenched in the geologic literature for the limestone beds between the Cibao Formation and the Aymamón Limestone, the name Aguada Limestone is retained, but a special reference section is designated on Highway 110,2 to $3 \mathrm{~km}$ north of Moca. The new reference section is about $9 \mathrm{~km}$ northeast of Aguada.
\end{abstract}

\section{INTRODUCTION}

The stratigraphic sequence of Oligocene and Miocene rocks in Puerto Rico was described in 1948 by Zapp, Bergquist, and Thomas. Detailed geologic mapping in northern Puerto Rico between 1957 and 1967 by Monroe and Briggs (Briggs, 1965; Monroe, 1962, 1963a, 1963b, 1967; Monroe and Pease, 1962) has confirmed the stratigraphic sequence of Zapp, Bergquist, and Thomas (1948), but it has resulted in minor differences in location of geologic contacts and in somewhat more precise location of contacts in stratigraphic sections. In northwestern Puerto Rico; however, mapping of the Moca and Aguadilla quadrangles by Monroe in 1965-67 has shown that the upper and lower contacts of the Aguada Limestone diverge significantly from those shown by Zapp, Bergquist, and Thomas (1948) and that the type area of the Aguada Limestone is within the outcrop belt of the underlying Cibao Formation as defined farther east. Figure 1 is a generalized reduction of the northwestern part of the map prepared by Zapp, Bergquist, and Thomas (1948); figure 2 is a generalized reduction of the maps of the Aguadilla, Isabela, and Moca quadrangles surveyed by W. H. Monroe in 1965-67. 


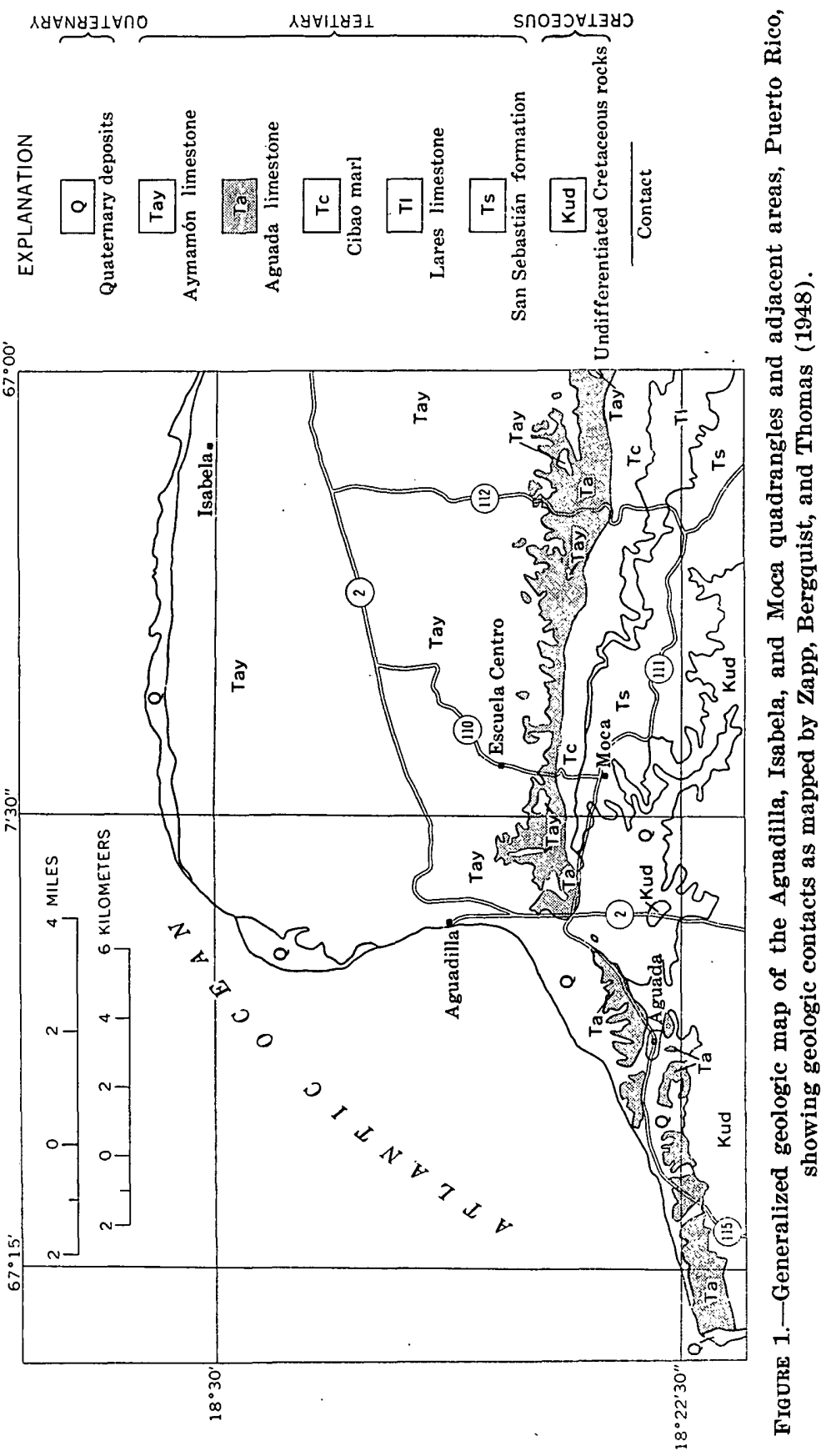




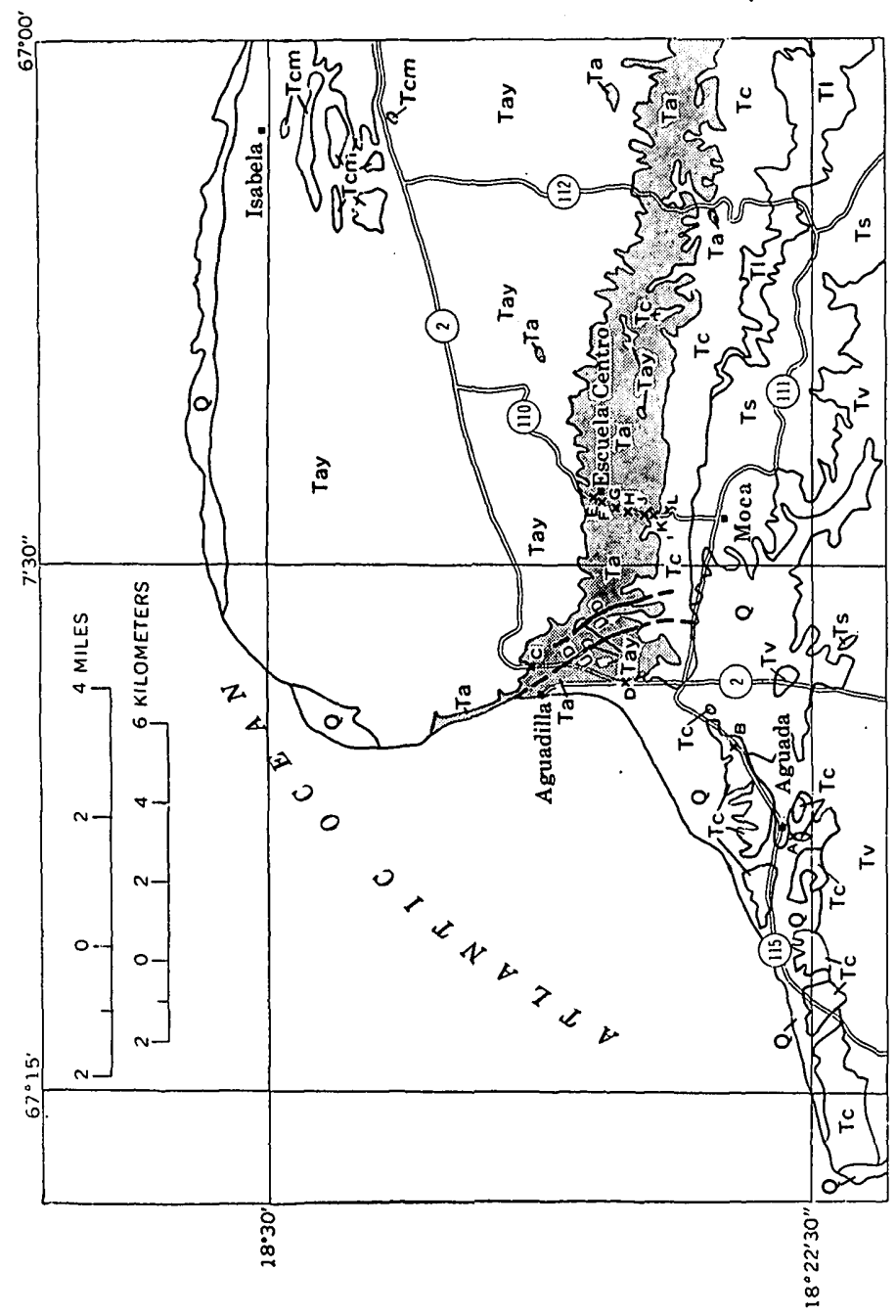

ชี่

Q 
During the preparation of this paper very helpful suggestions were made by H. R. Bergquist, R. P. Briggs, G. V. Cohee, and J. B. Epstein.

The paper was prepared in cooperation with the Commonwealth of Puerto Rico Economic Development Administration, Industrial Research Department.

\section{ROCKS EXPOSED IN NORTHWESTERN PUERTO RICO}

The rocks exposed in northwestern Puerto Rico consist of a basement of volcanic rocks largely of Eocene age, but possibly in part Cretaceous and Paleocene, overlain with angular unconformity by a sequence of sedimentary rocks ranging in age from middle Oligocene to Holocene. Most of the sequence of Oligocene and Miocene age is limestone, except in the lower part where beds of sand and gravel are present. The sequence is summarized in figure 3.

At the base is the San Sebastian Formation of the Río Guatemala Group, which consists of 0 to about 155 meters of sand and gravel but contains thin lenses of clay and very sandy clayey limestone. Fossils are abundant in some beds. The San Sebastián is not present in the extreme west near Aguada, unless a thin unmappable bed of lenticular sand and gravel at the base of the Cibao Formation may represent it. In the eastern part of the area, the upper part of the San Sebastian Formation intertongues toward the east with the Lares Limestone. The San Sebastian is overlain conformably by the Lares Limestone in the eastern part of the area shown in figure 2 and by the Cibao Formation in the central part where the Lares has intertongued with the upper part of the San Sebastián.

The Lares Limestone, also of the Río Guatemala Group, consists of 0 to $210 \mathrm{~m}$ of alternating beds of earthy limestone, hard coralline chalk, calcareous clay like the overlying Cibao, and thin lenses of sand and gravel similar to the underlying San Sebastián. Corals, oysters and other mollusks, and large Foraminifera are common.

The Cibao Formation at the top of the Río Guatemala Group consists of 250 to $280 \mathrm{~m}$ of interbedded calcareous clay, soft earthy chalk, and hard very fine grained calcarenite and nongranular limestone. In the eastern part of the area, the middle of the formation, the Guajataca Member, contains many lenses of sand and gravel as much as $15 \mathrm{~m}$ thick. The formation is generally fossiliferous; locally it contains many oysters, an abundance of other mollusks, a few corals, and a few large Foraminifera.

The Cibao is overlain conformably by the Aguada Limestone, which is about $90 \mathrm{~m}$ thick throughout the area. At the base of the Aguada is a bed of hard medium-grained calcarenite, 50 centimeters to several meters thick. At the eastern edge of the area, the lower $60 \mathrm{~m}$ (lower 


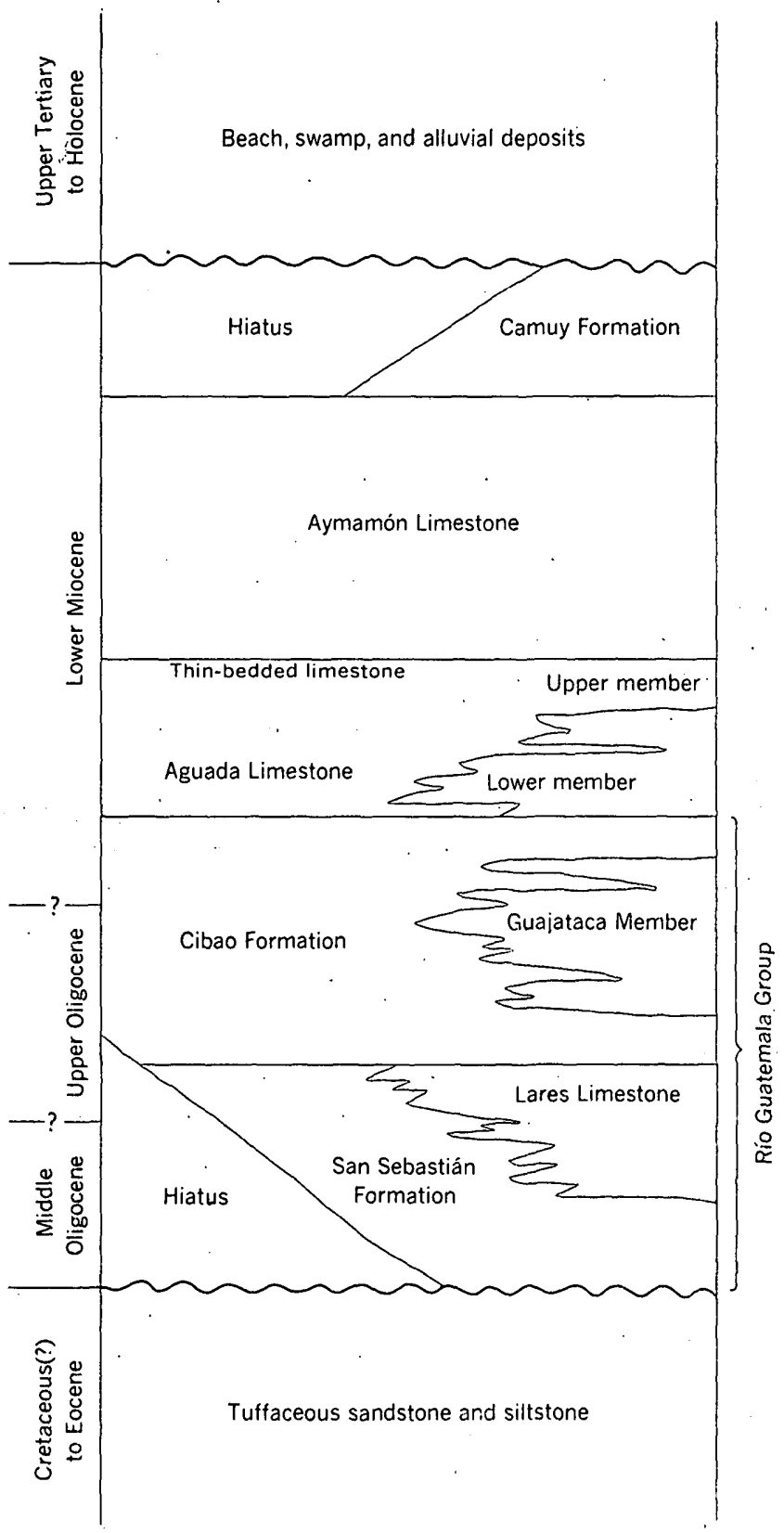

Frgure 3.-Diagrammatic section showing rocks exposed in northwestern Puerto Rico. 
member) consists of granular chalky soft limestone or marl, containing discontinuous beds of fine- to medium-grained fossiliferous calcarenite. Although this part of the formation resembles the Cibao, it contains much less clay. This lower member is overlain by thick layers of very pale orange to pink hard calcarenite alternating with chalky and rubbly limestone (upper member). In the western part of the area of outcrop shown in figure 2, the lower member grades laterally into hard calcarenitic limestone like the upper member farther east. The Aguada is locally fossiliferous, containing the foraminifer Marginopora sp., some corals, and a few molluska, but fossils are much less common than in the Cibao. Oysters are very rare. At the top and locally at lower positions, the formation contains 1 to $9 \mathrm{~m}$ of orange to pink granular thin-bedded and cross-laminated limestone in which individual beds range in thickness from 1 to $7 \mathrm{~cm}$. This thin-bedded zone has proved a useful marker for the top of the formation, as it has been found at or near this position in nearly all sections from Aguadilla to San Juan.

The Aguada is overlain sharply but probably conformably by the Aymamón Limestone, which is about $195 \mathrm{~m}$ thick. At most places the Aymamón consists of white to very pale orange, very pure fossiliferous limestone, generally indurated at the surface into finely crystalline rather dense limestone. In northwestern Puerto Rico, the upper $85 \mathrm{~m}$ contains many thick lenses or beds of very pale orange to brightyellow, slightly ferruginous chalk containing many beds of large oysters (Ostrea haitensis Gabb) and other fossils; these beds are interbedded with hard white limestone like the lower part of the formation.

The Aymamón is overlain near Isabela by the lower part of the Camuy Formation, which in this area consists of about $30 \mathrm{~m}$ of thinbedded and cross-laminated to massive ferruginous chalk and calcarenite varying in color from very pale orange to pale reddish brown.

Resting unconformably on all the rocks described above are discontinuous deposits of sand, clay, and sandy gravel of late Tertiary to Holocene age. In figures 1 and 2, only those deposits believed to be of Quaternary age are shown; most of these are alluvium and various kinds of beach deposits.

\section{AGUADA LIMESTONE}

The Aguada Limestone was named by Zapp, Bergquist, and Thomas in 1948:

The Aguada limestone is named from prominent exposures in the vicinity of the town of Aguada, near the west coast of the island. The Aguada limestone consists of the transitional beds between the underlying Rio Guatemala group 
und the overlying Aymamón limestone. It rests conformably on the Río Guatemala group where present, but southwest of Aguadilla and east of Bayamón, the Aguada limestone overlaps the [Cibao Formation of the] Río Guatemala group and rests unconformably on the Cretaceous rocks. The Aguada limestone is overlain conformably by the Aymamón limestone with which it is, in general, coextensive.

Geologic mapping in northern Puerto Rico by W. H. Monroe and R. P. Briggs between 1957 and 1967 has confirmed in general the mapping of the Aguada Limestone by Zapp, Bergquist, and Thomas (1948) in most areas except in northwestern Puerto Rico. Mapping in 1965-67 by W. H. Monroe has shown that in the Moca and Aguadilla quadrangles the contacts drawn by Zapp, Bergquist, and Thomas (1948) for the top and bottom of the Aguada become progressively too low toward the west and that the area near Aguada, chosen as the type area by Zapp, Bergquist, and Thomas, is entirely within the Cibao Formation as mapped elsewhere by them. Figures 1 and 2 show graphically the difference in the maps.

The distinctive thin-bedded limestone at the top of the Aguada Limestone is readily traceable throughout northern Puerto Rico. It is roughly at the top of the Aguada as mapped by Zapp, Bergquist, and Thomas as far west as the eastern part of the area shown in figures 1 and 2; still farther west it occurs at progressively higher stratigraphic positions than the upper contact shown on the 1948 map. It is obscurely exposed at two places near Highway 112 in the eastern part of the Moca quadrangle, well exposed at several places on Highway 110 in the western part of the quadrangle, and well exposed at several places in the eastern part of the Aguadilla quadrangle and on the new cuts of Highway 2 just east of Aguadilla; it can be followed down the face of the sea cliff north of Aguadilla and reaches sea level near the small U.S. Military Reservation about $3 \mathrm{~km}$ north of the center of Aguadilla. (The places mentioned above can be found on the topographic maps of the Moca and Aguadilla quadrangles.)

The lower two-thirds of the Aguada Limestone in the eastern part of the area shown in figure 2 contains much earthy limestone and some calcareous clay; at the base is a bed of medium-grained calcarenite $1 / 2$ to $1 \mathrm{~m}$ thick that is characteristic of the base of the formation farther east. This part of the Aguada, designated "lower member" on detailed maps (Monroe, 1967), resembles the underlying Cibao Formation, except that it contains much less calcareous clay. It seems probable that Zapp, Bergquist, and Thomas (1948) did not recognize the continuity of the thick bed of calcarenite at the base of the sequence, and farther west they correlated the upper part of the Cibao as defined herein with this lower member of the Aguada. In the western part of the area, the lower member grades laterally into hard limestone very 
much like the upper member. In the eastern part of the area shown in figures 1 and 2, Zapp, Bergquist, and Thomas (1948) correlated outliers of the harder upper member of the Aguada, as herein defined, with the Aymamón Limestone. In the area near Aguadilla, almost the entire Aguada was mapped with the Aymamón.

The sequence of rocks near the town of Aguada consists principally of somewhat lenticular, irregularly bedded, slightly ferruginous chalk and calcareous clay interbedded, especially at the base, with hard medium-grained calcarenite. The sequence is well exposed in a quarry and on building sites north of the quarry just west of the intersection of Highways 439 and 115 at marker $\mathrm{km} 26 \mathrm{hm}$ 0, Highway $115(62,100$ $\mathrm{m} \mathrm{N} . ; 74,900 \mathrm{~m} \mathrm{E}$.), ${ }^{1} 2.5 \mathrm{~km}$ northenst of the church in the plaza at Aguada. This site is marked B in figure 2. Although Zapp, Bergquist, and Thomas (1948) did not designate a type locality for the Aguada Limestone, this quarry is within the type area.

\section{Section of Cibao Formation exposed in quarry and on building sites on hill north of quarry $2.5 \mathrm{~km}$ northeast of Aguada}

10. Limestone, vuggy, fossiliferous, very finely crystalline, very pale orange; interbedded with rubbly chalk containing concretionary masses of limestone as much as about $5 \mathrm{~cm}$ in diameter. To top of hill

9. Chalk, very finely. crystalline, fossiliferous; containing scattered concretions of limestone as much as about $4 \mathrm{~cm}$ in diameter

8. Limestone, compact, very fine grained, chalky

7. Chalk, moderate orange-pink

6. Chalk, compact, rubbly, very pale orange; grading down into rubbly chalky, very finely crystalline limestone, locally cemented into compact limestone. Upper part very poorly exposed on hill north of quarry

5. Chalk, recrystallized into brown vuggy limestone; dendrites of $\mathrm{MnO}_{2}$

4. Marlstone, compact; interbedded with white chalk

3. Clay, chalky; containing oysters

2. Calcarenite, fine-grained; alternates with compact silty chalk; beds $20-50 \mathrm{~cm}$ thick

1. Limestone, compact, rubbly, chalky; to botton of quarry road.

\footnotetext{
1 The kilometer and hectometer markers along highways are renumbered from time to time, so that locations in this paper are also referred to the Puerto Rico metric grid which is shown on the borders of U.S. Geological Survey topographic maps of Puerto Rico. The numbers show the meters north and east of an arbitrary reference point south of Isla Mona and southwest of Puerto Rico.
} 
Although the strata in the vicinity of Aguada resemble the strata in the lower part of the Aguada Limestone in the eastern part of the area shown in figure 2, they are much more like the strata in the upper part of the Cibao Formation in that area and farther west. Furthermore, they contain several oyster-bearing beds, as does the Cibao, whereas oysters are very rare in the Aguada elsewhere in Puerto Rico. The thickness of the Aguada throughout most of northern Puerto Rico is about $90 \mathrm{~m}$, except downdip in the valley of the Río Grande de Manatí and the Río Grande de Arecibo, where Briggs (1961) reported thicknesses of as much as $140 \mathrm{~m}$. In order to include the strata near Aguada in the Aguada Limestone, the thickness of the Aguada would have to be at least $150 \mathrm{~m}$, probably as much as $180 \mathrm{~m}$.

Limestone is fairly common. in the lower part of the sequence near Aguada. This limestone resembles the limestone beds in the Cibao, but conceivably could be limestone of the Lares Limestone deposited west of the area in which thick masses of gravel were deposited during Lares time. This gravel generally has been included in the upper part of the San Sebastián Formation. The limestone does not look like any of that in the Lares in the eastern part of the area in figure 2, however, and it has not been feasible to map it separately from the gradationally overlying chalk, calcareous clay, and earthy limestone. Hubbard (1923, p. 43-44) mapped all the limestone, chalk, and calcareous clay near Aguada in the Lares Limestone.

The fossils found in the rocks near Aguada are mostly long-ranging species and are of little value in solving the problem. The presence of oysters suggests a correlation with either the Cibao or the Lares, for oysters are common in both of these formations and are very rare in the Aguada. H. R. Bergquist (written commun., probably 1945) collected Lepidocyclina (USGS colln. 17171; loc. A in fig. 2) from an outcrop of weathered buff limestone at the north end of an isolated hill $360 \mathrm{~m}$ south of Aguada; Lepidocyclina is common in the lower two-thirds of the Cibao and in the Lares but has not been reported from the Aguada.

Becarise of the doubt as to the assignment of the strata near Aguada, a special reference section for the Aguada Limestone is established about $9 \mathrm{~km}$ northeast of Aguada on Highway 110 between markers $\mathrm{km} 15 \mathrm{hm} 6$ and $\mathrm{km} 17 \mathrm{hm} 0$ from 2 to $3 \mathrm{~km}$ north of Moca. The dips in the area are generally north and range from $3^{\circ}$ to $4^{\circ}$.

The top of the Aguada Limestone is very well and characteristically exposed in a roadcut on Puerto Rico Highway 110 at Escuela Centro, marker $\mathrm{km} .16 \mathrm{hm} 6$ (E in fig. 2; 65,325 m N.; 80,790 m E.). This outcrop is on a hill capped by an outlier of Aymamón Limestone." 
Aymamón Limestone:

5. Limestone, massive, very pale orange, finely porous, very finely crystalline. To top of hill

Aguada Limestone:

4. Calcarenite, thin-bedded, cross-laminated, grayish-orange-pink to moderate-orange-pink, fine- to medium-grained; in beds $3-5 \mathrm{~cm}$

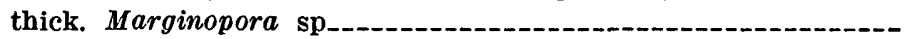

3. Calcarenite, hard, moderate-reddish-orange to grayish-orange fineto medium-grained; containing some solution cavities. No fossils seen

2. Clay, plastic, light-gray

1. Calcarenite, hard, pinkish-gray, fine-grained. Marginopora sp. From road level

Total thickness

Total thickness

Cuts on Highway 110 farther south expose lower parts of the Aguada. In the next deep cut at $\mathrm{km} 16 \mathrm{hm} 4.5$ (F in fig. 2), the thinbedded limestone of bed 4 of the section described above is underlain by $2 \mathrm{~m}$ of massive orange-pink to light-reddish-brown calcarenite perforated by abundant solution cavities. The calcarenite rests on about $5 \mathrm{~m}$ of a solution breccia of very finely crystalline limestone that closely resembles the Aymamón Limestone. This is underlain by medium- to coarse-grained, hard chalky calcarenite. No fossils were observed in any of these beds. A spring near the northern end of the cut flows out of a small cavern in the brecciated beds. The presence of gray clay at the bottom of the spring but not in the adjacent limestone suggests that bed 2 in the section at Escuela Centro may be a secondary deposit.

At $\mathrm{km} 16 \mathrm{hm} 2$ (G in fig. 2), still lower strata consist of very paleorange and grayish-orange-pink unfossiliferous limestone containing many black grains, probably $\mathrm{MnO}_{2}$. Similar rock is exposed at several other cuts farther south, one of which is at the bottom of a cliff of limestone about $15 \mathrm{~m}$ high. One small coral head was observed in a cut at $\mathrm{km} 15 \mathrm{hm} 9$.

The hard generally unfossiliferous limestone exposed in the series of roadcuts described above is underlain by about $5 \mathrm{~m}$ of coarsely rubbly, compact but not recrystallized, orange-pink chalky limestone that contains a few Kuphus tubes at $\mathrm{km} 15 \mathrm{hm} 7$ (H in fig. 2; $64,500 \mathrm{~m} \mathrm{~N}$.; $80,600 \mathrm{~m} \mathrm{E}$.). This material is characteristic of the lower part of the Aguada as exposed in the eastern part of the area shown in figure 2.

At $\mathrm{km} 15 \mathrm{hm} 6$ ( $J$ in fig. $2 ; 64,400 \mathrm{~m} \mathrm{~N}$.; $80,540 \mathrm{~m} \mathrm{E}$.), hard crystalline cavernous limestone stratigraphically below the chalky limestone of $\mathrm{km} 15 \mathrm{hm} \mathrm{7}$, and at the bottom of the Aguada, is exposed. The contact with the underlying Cibao Formation is covered by heavy forest 
growth here, but it is exposed on several hills farther south, where the basal bed of the Aguada consists of 1 to $2 \mathrm{~m}$ of medium-grained calcarenite that rests on calcareous clay. The Cibao is exposed on the west side of the highway at $\mathrm{km} 15 \mathrm{hm} 4$ ( $\mathrm{K}$ in fig. 2; 64,200 m N.; $80,510 \mathrm{~m} \mathrm{E}$.), where it consists of pink and yellowish-gray rubbly chalk containing Pecten sp., Kuphus sp., and Foraminifera.

Strata characteristic of the upper part of the Cibao Formation in this area are exposed in the cuts of Highway 110 near the top of the bluff north of Moca, from about $\mathrm{km} 14 \mathrm{hm} 8$ to about km 15 (L in fig. 2; $63,840 \mathrm{~m} \mathrm{~N}$.; $80,480 \mathrm{~m} \mathrm{E}$.). The top of this section is about $35 \mathrm{~m}$ below the top of the Cibao Formation.

\section{Section of Cibao Formation on Highway 110 at top of bluff $1.3 \mathrm{~km}$ north of Moca}

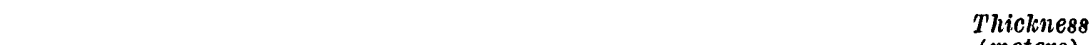
(meters)

Limestone, very chalky, rubbly. To top of cut about

Calcarenite, hard, grayish-orange, fine-grained; resembling Aguada Limestone

Marl, moderate orange-pink to pale-yellowish-orange, fine- to mediumgrained, chalky; crudely stratified into beds $2-15 \mathrm{~cm}$ thick

Clay, very light bluish gray (generally weathered to tan), silty, calcareous ; containing impressions of fossils ; abundant large pelecypods and gastropods in lower part; crudely bedded to massive

Clay, similar to above; crudely stratifled in layers about $1 / 2 \mathrm{~m}$ thick ; gastropods and Marginopora sp.

Limestone, crudely bedded, marly, less distinctly bedded than above; abundant fragments and molds of pelecypods, gastropods, corals, and one echinoid ; base very sharp, forming small overhang-_.--_.--_-.--

Siltstone, soft, calcareous, fossiliferous

Breccia of calcareous nodules 1 to $2 \mathrm{~cm}$ in diameter, a few as large as $5 \mathrm{~cm}$ grading down into massive slightly rubbly marlstone; Orthaulax sp.---

Total thickness

30.5

Concealed below by landslide debris.

The new cuts on the long north-south slope of Highway 2 just east of Aguadilla, $5 \mathrm{~km}$ northeast of Aguada, include the entire sequence of the Aguada Limestone, but at most places the strata are broken except for short distances, because at least two north-northwest-trending fault zones cut through the formation. These exposures are suitable as another reference locality where the rocks have many of the characteristic lithologic features of the Aguada Limestone. The base of the formation consists of thick beds of medium- to coarse-grained calcarenite and is exposed east of the southern edge of Aguadilla at marker $\mathrm{km} 128 \mathrm{hm} 9.5$ (D in fig. 2; 64,650 m N.; 76,400 m E.). The thin-bedded limestone, $9 \mathrm{~m}$ thick, at the top of the formation is typically exposed at $\mathrm{km} 126 \mathrm{hm} 0$ (C in fig. 2; 67,510 m N.; 76,890 m E.). 


\section{REFERENCES CITED}

Briggs, R. P., 1961, Geology of Kewanee Interamerican Oil Company test well No. 4CPR, northern Puerto Rico, in Oil and gas possibilities of northern Puerto Rico : San Juan, Puerto Rico Mining Comm.; p. 1-23.

- 1965, Geologic map of the Barceloneta quadrangle, Puerto Rico: U.S. Geol. Survey Misc. Geol. Inv. Map I-421.

Hubbard, Bela, 1923, The geology of the Lares District, Porto Rico : New York Acad. Sci., Scientific Survey of Porto Rico and the Virgin Islands, 'v. 2 pt. $1,115 \mathrm{p}$.

Monroe, W. H., 1962, Geology of the Manati quadrangle, Puerto Rico: U.S. Geol. Survey Misc. Geol. Inv. Map I-334.

1963a, Geology of the Vega Alta quadrangle, Puerto Rico: U.S. Geol. Survey Geol. Quad. Map GQ-191.

1963b, Geology of the Camuy quadrangle, Puerto Rico: U.S. Geol. Survey Geol. Quad. Map GQ-197.

1967, Geologic map of the Quebradillas quadrangle, Puerto Rico: U.S. Geol. Survey Misc. Geol. Inv. Map I-498.

Monroe, W. H., and Pease, M. H., Jr., 1962, Preliminary geologic map of the Bayamón quadrangle, Puerto Rico: U.S. Geol. Survey Misc. Geol. Inv. Map I-347.

Zapp, A. D., Bergquist, H. R., and Thomas, C. R., 1948, Tertiary geology of the coastal plains of Puerto Rico: U.S. Geol. Survey Oil and Gas Inv. Prelim. Map 85, 2 sheets. 